\title{
THE NORTHERN COAL-OWNERS AND THE OPPOSITION TO THE COAL MINES ACT OF 1842
}

\begin{abstract}
"Never have I seen such a display of selfishness, frigidity to every human sentiment, such ready and happy self-delusion", wrote Lord Ashley of the opposition to his coal-mines bill in the House of Lords. Historians have tended to confirm Ashley's judgement, and agreed that the motives of the Northern coal-owners in opposing the bill were inspired by simple selfinterest, a desire to preserve their right to dispose of their pits, and the men, women and children in them, as they saw fit. ${ }^{1}$ It would, of course, be naive to suggest that the Northern coal-owners were not self-interested, but it is perhaps worth analysing the nature of that self-interest, which was not, as the simple and usual dismissal of it would suggest, merely an assertion of proprietorial rights.
\end{abstract}

The first clause of Ashley's bill prohibited the employment of women and girls in mines and collieries. None of the opponents of the bill were hostile, in principle, to the exclusion of females. The bill's leading opponent in the Commons, Peter Ainsworth, the coal-owning MP for Bolton, confessed that he had "not the slightest objection" to the exclusion of women, while E. B. Denison, expressing the hostility of his West Riding constituents to the bill in general, agreed that "all were united in opposing the employment of women in collieries". In the Lords, too, the leading opponents were prepared to accept the exclusion of women. Lord Hatherton thought the employment of women "unnecessary; that it had an immoral and injurious tendency; and that it ought not to be permitted", while even Lord Lon-

1 Ashley's diary, 26 July, in E. Hodder, The Life and Work of the Seventh Earl of Shaftesbury, K.G. (London, 1887), I, p. 431. All dates cited refer to the year 1842, unless otherwise specified. For the traditional view of the coal-owners, see, e.g., J. L. and B. Hammond, Lord Shaftesbury (London, 1969), pp. 75-83. 
donderry announced that "he was opposed to the employment of women in the mines". 2

If objections were raised to the bill's first clause, it was principally on the score of hardship. Lord Ashley thought that the vacancies in pit-work created by the exclusion of women would provide opportunities for the unemployed. "The hand-loom weavers (poor people!)", he wrote, "rejoice in the exclusion of the females, as they themselves will go down and take their places", 3 and Lord Devon, moving the second reading of the bill in the Lords, thought that "hundreds of those persons who were thrown out of work in the manufacturing districts would be glad to get employment in the mines". ${ }^{4}$ The bill's opponents, however, prophesied hardship for those excluded from the pits. Ainsworth believed the exclusion "just now" would increase an already great unemployment among the poor. Londonderry agreed that "in a majority of instances" women would get no other work, and read a letter from Sir George Clerk, who thought that "the women, by being excluded from working in the collieries, will be deprived of obtaining the means of subsistence." Privately Londonderry wrote to the Prime Minister to express his fear that "if this measure is forced forward this session [...] the females turned adrift will be absolutely starving". ${ }^{6}$ Lord Wharncliffe told the House of Lords that "he thought the measure would not in many parts of the country be hailed as a boon, for its effect would be to create great distress in numerous districts", an opinion which the statement of Rebecca Hough, a fourteen-year-old hurrier from Wharncliffe's County of Yorkshire tended to confirm: "I don't like being in the pit", she confessed to the Children's Employment Commissioners, but she had not tried to get any other work "because I know I could not, there is over many out of place already."7 Lord Hatherton felt that widows with children to support should be omitted from the bill's provisions, while the Duke of Buccleuch (who supported the bill) and the Duke of Hamilton (who opposed it) both presented petitions from Scotland asking that women already in the pits might be allowed to continue. Lords Dunmore and Skelmersdale also suggested the exemption of various categories of wo-

2 Hansard's Parliamentary Debates, Third Series, LXIV, cc. 784, 936, 999; LXV, c. 118.

3 Ashley's diary, 16 June, loc. cit., p. 426. Men like John Fielden or William Cooke Taylor may have disputed this claim, see D. Bythell, The Handloom Weavers (Cambridge, 1969), p. 255. For handloom weavers becoming pitmen, cf. ibid., p. 262.

${ }^{4}$ Hansard, LXV, c. 109.

5 Ibid., LXIV, c. 999; LXV, cc. 119-20.

6 Londonderry to Peel, 20 July, Peel papers, British Library, Additional Manuscripts 40512, ff. 35-36.

${ }^{7}$ Hansard, LXV, c. 122; Children's Employment Commission (hereafter CEC), Appendix to First Report, Pt I [Parliamentary Papers, 1842, XVI], p. 265. 
men, the latter proposing a sworn statement before a Justice of the Peace (who was not himself to be a coal-owner) that the woman in question was willing to work. ${ }^{8}$

When the Act was passed, many of the opponents' fears were shown to have been justified. A South Wales miner complained that if his three daughters who worked with him in the pit, lost their jobs, "the whole family must become inmates of the Union workhouse, as his own labour and exertions could not support them." $\mathrm{C}$. L. Cumming Bruce pointed out the hardship caused in Scotland by the exclusion of women from pit-work. In the parish of Polmont, in Stirlingshire, 200 women had been thrown out of work; at Elgin colliery 108 women lost their jobs, thirty-eight of whom had sixty-nine dependant relatives who were now quite destitute; at Fordel fifty women were discharged, thirty-four of whom were the sole support of sixty-three others. In all Bruce listed ten collieries, which had between them laid off 1,000 women, with resultant "idleness and destitution". Appealing for an amendment to Ashley's Act at least to permit unmarried women, and widows over eighteen, who wished to resume work to do so, Bruce suggested that Ashley's "zeal in the cause of humanity", which he conceded to be much to his credit, "had a tendency to make him overlook the practical difficulties in his way", and also, by acting "too rapidly, and without sufficient caution", Ashley had ignored "the amount of suffering and distress" that might result from the fulfilment of the objects "he had so meritoriously in view". ${ }^{10}$ Londonderry's view that "practical benevolence was more praiseworthy than mistaken humanity" was in marked contrast to the view expressed by Lord Campbell, a supporter of the bill, that "even a workhouse would be preferable to the slavery of the mines". ${ }^{11}$

Of course, the coal-owners did not admit that work in the mines was "slavery". Fitzwilliam insisted that employment in agriculture was as harmful as that in the mines. Londonderry claimed that Irish women digging potatoes half-naked were every bit as degraded as colliery women, and that it was "harder work". Perhaps few would have agreed with the Duke of Hamilton's assertion that labour in mines was "sweet" to the pit women, but several witnesses bore testimony to the fact of its being preferable to domestic service. Two women told Dr Walker, a Stirlingshire magistrate, in 1843, that they preferred pit-work to their former occupation

8 Hansard, LXV, cc. 123-24, 316-17, 586-87.

9 J. H. Morris and L. J. Williams, The South Wales Coal Industry, $1841-1875$ (Cardiff, 1958), p. 215.

${ }_{10}$ Hansard, LXIX, cc. 429-57.

11 Ibid., LXV, cc. 582, 586. The Morning Post, 26 July, toned down Campbell's speech to read: "He could scarcely think the alternative of the workhouse worse than their present condition." 
as domestic servants, as it was not such hard work, and that it was, as well as being easier than field labour, "more healthy as being less exposed to the vicissitudes and inclemencies of the weather". ${ }^{12}$ Charlotte Chiles preferred the work at Graig colliery near Merthyr Tydvil to her former post as kitchen maid to Lord Kensington, because the work was "not so confining, and I get more money. [. . . I I can get more dress and more liberty", and Hannah Clarkson, a sixteen-year-old hurrier from Silkstone said that, though she would rather be in service than down the pit, she would rather send her daughter down the pit than see her go hungry. ${ }^{13}$

Significantly, many of those who opposed the exclusion of women did not themselves come from coal districts where women were employed. Lord Hatherton pointed out that "the employment of females was unknown" in his part of Staffordshire, ${ }^{14}$ while Londonderry repeatedly asserted that no women or girls were employed in the coalfield of Northumberland and Durham. Indeed, if there was self-interest in Londonderry's attitude to the exclusion of women, it should have been the self-interest of complacency. His agent, John Buddle, while rebutting Lord Ashley's charges of indecency against women in the pits, and claiming that in his experience girls and women who worked underground seemed in "robust good health", nevertheless added: "I do not consider underground work a fit occupation for women, and have always been opposed to it." However, in the circumstances of Ashley's bill, Buddle simply dismissed the whole subject. "The employment of females does not apply to, or affect, the coal-owners of Northumberland and Durham", he wrote; clearly if it did not affect his employer it was, in Buddle's view, not worth consideration. ${ }^{15}$ Another agent, James Loch, was accused by Ashley of "secretly setting men's minds against the 'female clause", but his employer's wife, Lady Francis Egerton, had already insisted in July 1841, before the Children's Employment Commission had concluded their work, that no further women should be employed in the Bridgewater collieries. As early as February 1838, plans had been drawn up to find alternative employment for the women in Egerton's collieries in iron and cotton

12 Hansard, LXIII, cc. 197-98; LXV, cc. 118, 316-17; LXIX, c. 437.

13 CEC, Appendix to First Report, Pt I, p. 257; id., Pt II [PP, 1842, XVII], p. 516. Janet Neilson, from Fife, "much prefers service", but supposed her father needed her earnings, Pt I, p. 514.

14 Hansard, LXV, cc. 111-12.

15 Buddle, "Comments on Ashley's Speech", National Coal Board Manuscripts I/ JB/1788 Durham County Record Office; id., "Remarks on Lord Ashley's Bill, clause by clause", ibid., 1795. Cf. Buddle to Londonderry, 14 May, in which Buddle describes the employment of women as "an abomination", Londonderry Manuscripts D/Lo/C 142 (1313), Durham County Record Office. 
manufacturing, and though Loch did argue for delay in implementing the female clauses of Lord Ashley's bill, believing like others that alternative employment would be hard to find (and incidentally suggesting that the most common result would be to force "women who are virtuous" to drift into prostitution), once the Act was passed Loch ensured that the young girls under his management were trained for domestic service, the elderly women given relief from Lady Francis Egerton's charities, and those between found agricultural work on the estates. The Egertons, at least, responded to Ashley's injunction to coal-owners concerned about unemployment - "put your hands in your pocket!"16

Londonderry, it is true, sounded a monetary note in his cautions about excluding women. If men were required to do women's work, the price of coal would go up, and many collieries would become uncompetitive, and be forced to close. But Londonderry added that the men knew that their jobs were thus put at risk, and for that reason favoured the continued employment of women. ${ }^{17}$ Ainsworth, too, argued that "it was, in fact, a labourers' question", ${ }^{18}$ while Cumming Bruce, refuting Londonderry's implication that it was a question of profit, claimed "this was no coalowners' question"; he had re-opened the question of the employment of women "solely at the earnest request of the colliers themselves". 19

\section{II}

Ashley's second proposal, as introduced, was that all boys under thirteen years of age should be excluded from work in the pits. "This", he admitted, "may be looked upon as my weak point; for here I am likely to find the greatest opposition." Ashley was proved right. Opposition was of two types: first, a claim that children in the pits were comparatively well looked after, and secondly, and apparently more convincingly, a claim that he had set his minimum age too high. Ainsworth said he wished all the poor children in Lancashire were as well fed as the pit children, "but by this bill they would all be reduced to the same level of privation and suffering"; pit children, he claimed, were at present better off than factory children, but

16 Ashley's diary, 28 June, loc. cit., p. 428; F. C. Mather, After the Canal Duke (Oxford, 1970), pp. 322-23; Hansard, LXIX, c. 438.

17 Hansard, LXV, c. 119. Londonderry also warned that poor rates must go up, or be subsidised from, for instance, increased excise duties, ibid., c. 582.

18 Ibid., LXIV, c. 1000.

19 Ibid., LXIX, c. 444. A Scottish miner, opposing Cumming Bruce's motion in a speech at Newcastle, 11 March 1843 , "trusted that every pitman would be prepared to resist the slightest tampering with Lord Ashley's bill”, Hamilton-Russell Manuscripts, Northumberland County Record Office, 602/25/15.

20 Hansard, LXIII, cc. 1339-40. 
the effect of the bill would be to "deteriorate their condition". ${ }^{21}$ In the House of Lords Hatherton claimed that in Staffordshire "the day labourers almost invariably endeavour to procure their sons to be employed as colliers, but there were never any colliers who would submit to the degradation of their sons being day labourers." Lord Brougham, who was on the whole sympathetic to the bill, thought that if many other occupations were investigated they would yield an equally horrifying picture, while Fitzwilliam believed "that a boy employed in a colliery, who has his belly full morning, noon, and night, might perhaps be more healthy than the boy who was the son of an agricultural labourer, whose father earned no more than 7s. a week."22 Londonderry claimed that in the Durham pits boys were well used and carefully provided for, while the assembled coal-owners of the North-East attempted to assert that young children in mines were "generally cheerful and contented", and suggested that trappers spent their days whittling sticks, modelling with clay, or drawing with chalks. ${ }^{23}$ The Hammonds properly dismissed this sophistry, but more recent research has suggested that men like Fitzwilliam and Londonderry were, by contemporary standards at least, benevolent employers, ${ }^{24}$ while Lord Francis Egerton, whose agent Loch was active behind the scenes against the bill, was acclaimed by contemporaries for his "solicitude for the welfare" of his employees. ${ }^{25}$

The proposed age limit of thirteen from the first provoked hostility. Sir James Graham, welcoming the bill in general on behalf of the government, thought that some of Ashley's reasons for suggesting thirteen as the age limit "did not appear to be quite satisfactory", and reserved judgement on that part of the bill. Joseph Hume from the opposition benches agreed; the "question as to age" was, he felt, the only controversial part of the bill. ${ }^{26}$ Hedworth Lambton, brother of Lord Durham, until his recent death one of the most powerful coal-owners in the North-East, "at once admitted that the boys went into the mines too young", but disputed Ashley's claim that children of five were employed in the Durham coalfield. Lambton, and

21 Ibid., LXIV, cc. 1000-01.

22 Ibid., LXIII, cc. 197-98; LXIV, cc. 783-84; LXV, cc. 575-76.

23 Ibid., LXIII, c. 197; LXIV, c. 542, note.

24 J. L. and B. Hammond, Shaftesbury, op. cit., pp. 77-81; G. Mee, Aristocratic Enterprise: The Fitzwilliam Industrial Undertakings 1795-1857 (London, 1975); A. J. Heesom, "Entrepreneurial Paternalism: The Third Lord Londonderry and the Coal Trade", in: Durham University Journal, New Series, XXXV (1974), pp. 238-56.

${ }^{25}$ C. C. F. Greville, A Journal of the Reign of Queen Victoria, 1837-1852 (London, 1885), II, p. 304. Greville was Egerton's brother-in-law; but cf. sub-commissioner Kennedy in CEC, Appendix to First Report, Pt II, pp. 152, 194.

26 Hansard, LXIII, cc. 1357-58. 
Matthew Bell, the coal-owning MP for Northumberland, both argued that the real reason for children being in the pits was "solely the result of the conduct of their parents". It made no difference to the owners, said Lambton, "as far as self-interest was concerned", whether boys were employed at nine or ten, eleven or twelve; it was the parents who thought exclusively of the "few shillings" their children might earn. ${ }^{27}$

Lambton himself had already made inquiries from John Buddle, premier viewer of the North-East, as to how young children in the pits under his supervision (largely, but not exclusively, those of Lord Londonderry) began work, and what Buddle thought was a proper starting age. "What would be the effect", he asked, if Ashley's bill "should propose that no boy shall work in the mines before the age of 16 , or 17 or 18 years - it seems to me unnecessarily old, but I want you to show me how such a law would act injuriously on all parties - coalowners and working men." Buddle had received Lambton's inquiry while attending an executivecommittee meeting of the Northern Coal Trade, in Newcastle, and had taken the opportunity of consulting three or four of his "brother viewers" for their opinions on the minimum age at which boys should be employed. "We concurred in opinion", he said,

that the limitation ought not to exceed ten, or eleven, but say 11 years of age for initiating boys in pit-work - as we are decidedly of the opinion that if they are not initiated before they are 13 or $14-$ much less 16,17 , or $18-$ they never will become colliers.

Under the impression that Ashley was to propose a minimum age of sixteen, Buddle thought the coal trade would be plunged "into a state of utter confusion and disorganisation", and urged Lambton to secure a more reasonable minimum. "I hope you will be able to limit the age - if any limitation at all is to take place - to not exceeding [sic] 11 years." 28

Ashley had complained that from the time a child entered the mine "he learns nothing more than to be a miner". ${ }^{29}$ Buddle agreed, but argued that,

27 Ibid., cc. 1353-54, 1361. Of South Durham, the Children's Employment Commission wrote: "in this district children are sometimes taken down into the pits as early as five years of age, and by no means uncommonly at six"; in North Durham (where the Lambton collieries were) one case was recorded "in which a child was taken into the pit at four and a half years old; and several at five and between five and six", CEC, First Report [PP, 1842, XV], p. 28.

28 Lambton to Buddle, 13 and 27 May, National Coal Board Manuscripts I/JB/1782, 1785; Buddle to Lambton, 28 May, ibid., 1786. I have referred, as they did themselves, to the united coal-owners of Northumberland and Durham as the Northern Coal Trade; the same phrase, lower-case, is used as a general description for the coal-owners in the North of England.

29 Hansard, LV, c. 1264. 
in order to train a miner, it was essential to start young. Though he never went so far as those from Wakefield or Huddersfield who claimed that children in the thin seams could not easily acquire the necessary "posture" for pit work after the age of nine, ${ }^{30}$ or the humane Lord Francis Egerton, who quoted in apparent agreement a clergyman who "unwillingly but conscientiously" asserted that "the peculiar bend of the back and other physical peculiarities requisite to the employment could not be obtained if the children were initiated at a later age than twelve", ${ }^{31}$ Buddle was nevertheless convinced that a pitman, to be a good one, as well as to have any chance of progress in his profession, had to start young. Colliers, he claimed, could "never be recruited from an adult population; it is like bringing lads up to the sea - only the pit lad's life is incomparably better and more comfortable than the sailor's." 32 If children went late down the pit, Buddle told Lambton, they would have acquired "habits of idleness". ${ }^{33}$ Ten years old, he concluded, should be the "minimum age for employing lads in the pit. If they go later they will not take so kindly to it." ${ }^{34}$ Though a Yorkshire collier, David Swallow, asserted that "it is monstrous to say they will never make good colliers after the age of 10 or 11 ", and claimed that he could teach anyone "the business of a collier in three months", 35 the owners from Yorkshire shared Buddle's view. Colliers, they said, "seldom attain the requisite proficiency in their trade unless they enter the pits when young." 36 Buddle's native Tyneside not surprisingly also shared his views. At their meeting on 13th June 1842 the United Committee of the Northern Coal Trade passed a series of resolutions on Ashley's bill. The first stated

That in the opinion of this meeting the age of 10 years is the proper period at which boys should be taken down the pits, to commence the easy employment [sic] in which they are first engaged,

while the second echoed Egerton in stating:

It is the opinion of this meeting, founded on long experience, that after the age above mentioned the boys do not acquire those habits which are peculiarly necessary to enable them to perform their work in the mines.

The United Committee recited the arguments, similar to those applied to women, that the exclusion of children over ten would cause hardship to

30 CEC, Appendix to First Report, Pt I, p. 174.

31 Hansard, LXIII, c. 1356.

32 Buddle to Londonderry, 16 May, Londonderry Manuscripts 142 (1315).

33 Buddle to Lambton, 28 May.

34 Buddle, "Comments on Lord Ashley's Speech".

35 CEC, Appendix to First Report, Pt I, p. 285.

${ }^{36}$ Hansard, LXIV, c. 545, note. 
their families, and, after urging that the age of winding enginemen should be eighteen, rather than twenty-one, as Ashley proposed, concluded with a final resolution

That Mr. Buddle be instructed to wait on Lord Ashley to explain the views of the Committee; and to obtain the assistance of Lord Londonderry, Mr. Bell, Mr. Lambton, or any other Nobleman or Gentleman connected with the North in enforcing these opinions. ${ }^{37}$

The story of Buddle's mission to London is a familiar one ${ }^{38}$ Buddle was clear that he went not, as Hedworth Lambton later claimed, "to negotiate the best terms with Lord Ashley", but to meet with others "to induce" Ashley to accede to the "unanimous opinions" of the United Committee. ${ }^{39}$ Buddle arrived in London on 15th June, and the following morning conducted the private business with Londonderry's solicitor, the necessity for which had been the reason for his being chosen to travel south by the United Committee. He then saw Londonderry, who agreed to arrange a meeting with Ashley. Next he called on Hedworth Lambton, who, though sticking to his view that ten was too young, and preferring eleven or twelve, suggested that as he could not agree with Buddle "he would not say anything" on the question of age when together they met Ashley. The following day (17 June) Buddle called on Matthew Bell, "who entirely concurred in [his] views as to the age of ten being the right standard", and on the 18th Buddle had a private meeting with Ashley. Ashley remained "extremely tenacious" of his view that thirteen should be the minimum age, but after a long discussion offered to accept Buddle's idea of ten, provided the young children worked only six hours a day, or three days a week. "He offered to compromise the matter with me at once on those terms", Buddle recorded, but "this I declined to do, not thinking it prudent to take such a degree of responsibility on myself." Buddle noted in his diary

37 Coal Trade United Committee Minutes, 1840-44, pp. 170-72, Coal Trade Papers, Northumberland County Record Office.

38 A. J. Taylor, "The Third Marquess of Londonderry and the North East Coal Trade", in: Durham University Journal, New Series, XVII (1955-56), pp. 23-24; Heesom, "Entrepreneurial Paternalism", loc. cit., pp. 240-42; C. E. Hiskey, "John Buddle (1773-1843): Agent and Entrepreneur in the North East Coal Trade" (unpublished M.Litt. thesis, University of Durham, 1979), pp. 292-94.

39 Lambton to Morton, 24 June, National Coal Board Manuscripts I/JB/1793; Buddle to Lambton, 27 June, ibid., 1794; id. to Londonderry, 9 July, ibid., 1801; Hansard, LXV, cc. 3-4. Buddle's view of his role is borne out both by the original resolution of the United Committee, with its talk of "enforcing opinions", and his own diary, clearly written from day to day, where he recalls his instructions as being "to endeavour to get Lord Ashley to fix the minimum age for lads to be initiated in pit-work at ten, instead of thirteen". Buddle's place-book, Buddle Manuscripts, Shelf 47A, Vol. 13, pp. 149-51, North of England Institute of Mining and Mechanical Engineers, Newcastle. 
that Ashley had seemed very anxious that the question of age and hours of labour should be agreed by the coal-owners, apparently from a fear (justified in the event) that government support, held out by Graham, would evaporate. Buddle insisted that matters must be kept open, but on Monday 20th June he called on Bell again, who "agreed to recommend a compromise" on the lines Buddle had discussed with Ashley, when they all met at the House of Commons that afternoon. ${ }^{40}$

The meeting at the House of Commons was chaired by Lord Francis Egerton, and as well as Ashley, Lambton, Bell and Buddle, included Lord Wharncliffe, several Durham MPs (Lord Harry Vane, John Bowes, H. T. Liddell and T. C. Granger) James Loch (Egerton's agent and MP for Wick), and Joseph Brotherton (MP for Sheffield and a supporter of the bill). ${ }^{41}$ Buddle's version of the meeting, as reported to Londonderry the following morning, was that

after much discussion, Lord Ashley consented to modify those clauses which bore hardest upon us so as to render them perfectly innocuous \& it was therefore agreed not to offer any opposition [...] in the Commons. ${ }^{42}$

Hedworth Lambton recalled the meeting as follows:

Mr. Buddle [and] the County Members of Durham and Northumberland meet Ld. Ashley - discuss the whole matter - concessions are made on both sides - an agreement is come to on both sides unanimously - it is then distinctly understood that with these concessions we are prepared to support the Bill. ${ }^{43}$

On the 22nd June Ashley told the Commons of the compromise that had been agreed, and received Hedworth Lambton's support for his bill, as amended. ${ }^{44}$

Two days later Lord Londonderry presented a petition to the House of Lords from the Northern Coal Trade, praying for delay in implementing the bill. ${ }^{45}$ Londonderry himself had prompted the petition. As soon as the Children's Employment Commission report had been published, the Bishop of Norwich had presented petitions calling for legislation, and had

${ }^{40}$ Buddle's place-book, 15-20 June, pp. 151-55; Taylor, "The Third Marquess of Londonderry", loc. cit., p. 23, note 15, mistranscribes the date "June 18th 1842. Saturday" as 17 June.

${ }^{41}$ Buddle's place-book, 20 June; Taylor, loc. cit., p. 23, note 17, omits Egerton; confuses Lord Harry Vane, MP for South Durham, and no relation to Londonderry, with Henry Vane, Viscount Seaham, Londonderry's son; and also confuses James Loch with James Losh, a Newcastle coal agent who died in 1833.

${ }^{42}$ Buddle to Londonderry, 21 June, Londonderry Manuscripts 142 (1316).

43 Lambton to Morton, 24 June.

${ }^{44}$ Hansard, LXIV, c. 426.

45 Ibid., cc. 538-44; Morning Post, 25 June. 
clashed with Londonderry over the extent of the evils portrayed in the report. ${ }^{46}$ Londonderry was furious. "I want to set this Bishop on the floor", he told Buddle, and wrote to R. W. Brandling, chairman of the United Committee of the Northern Coal Trade, that "in consequence of the Bishop of Norwich's statement and the petition he presented" and his own denial of these abuses in the north generally and in Durham in particular, the assembled coal owners at Newcastle should embody "their contrary denials" in a petition "from the whole body". 47 Petitions were duly prepared for signature, and it was agreed to send copies to Londonderry for presentation to the Lords, and to Bell for the Commons. ${ }^{48}$

Buddle, of course, knew of these petitions, and discussed the presentation of them with Londonderry in the intervals of his "negotiation" with Ashley. Waiting to hear the outcome of Buddle's meeting at the Commons, Londonderry assured him that "whatever may be your agreement as to the bill, I think a temperate exposition, the first day I can get, of some of the facts and details in my possession will be of public utility", and consequently he presented his copy of the petition on 24th June. ${ }^{49}$ Hedworth Lambton was furious. "Can it be possible", he asked Lord Durham's agent, Henry Morton, that "the same persons who were represented by $\mathrm{Mr}$. Buddle, and who are in all honour bound by the agreement and understanding come to by Mr Buddle", should give Lord Londonderry a petition to present "in the very face of the agreement come to formally by their delegate and representative Mr. Buddle"? If such was the case, Lambton said, then Lord Ashley "will have fair right to complain of a discreditable breach of promise". ${ }^{50}$

Ashley, however, did not see the presentation of the petition by Londonderry in the same light. On June 28 th, four days after Londonderry presented the Northern Coal Trade's petition, Ashley wrote to Buddle to thank the "gentlemen connected with the coal-trade in Northumberland and Durham" for their "kind, honourable, and disinterested course", adding that he felt particularly indebted "to all the Members for those Northern districts, but more especially to the activity and kindness of Mr. Lambton and Mr. Bell". ${ }^{51}$ It was Buddle's reply to this letter, rather than

\footnotetext{
46 Hansard, LXIII, cc. 196-99.

47 Londonderry to Buddle, 12 May, National Coal Board Manuscripts I/JB/178I; id. to Brandling, 28 May, Coal Trade United Committee Minutes, 1840-44, p. 166 b.

48 Notice of petition, 8 June, Coal Trade Papers, Coal Trade Reports 1833-54; Buddle's place-book, 6 June, p. 146.

49 Buddle to Londonderry, 19 June, Londonderry Manuscripts 142 (1317); Londonderry to Buddle, 21 June, National Coal Board Manuscripts I/JB/1791.

50 Lambton to Morton, 24 June.

51 Ashley to Buddle, 28 June, National Coal Board Manuscripts I/JB/1796.
} 
Londonderry's speech and petition in the Lords, which provoked in Ashley a sense of betrayal. Buddle explained the problem to Londonderry:

On returning to the North, I found the [.. .] compromise not at all satisfactory either to the Commee or the Body of Coal-Owners generally especially as to the alternate day's working of the Boys which will be attended with many practical difficulties. ${ }^{52}$

Thus, while sending Ashley a formal letter of acknowledgement on behalf of the United Committee, Buddle added a private letter of his own, so that Ashley should understand that the United Committee were still insisting on delay in implementing any legislation. The Committee, he told Ashley, "have ascertained that the general feeling of the Trade is in favour of the proposed restriction of the age of the children to ten years." But, he added, the proposal to limit their working week to three alternate days was "considered to be very objectionable. And it is thought by a large majority of the Trade that there ought to be no alteration in this respect." 53 Ashley was "astonished" by this letter, which he saw as a "departure from the engagement into which I entered during my interview with yourself and the gentlemen representing the coal districts". ${ }^{54}$ Buddle, in reply, could only regret that there had not been time, between the meeting at the House of Commons on the 20th June, and the committee stage of the bill, when the "compromise" was announced, on the $22 \mathrm{nd}$, to communicate with the United Committee in Newcastle. If such communication had been possible, Buddle believed "any misapprehension as to the extent of my instructions might have been avoided". Though Buddle reminded Ashley that, at their private interview, he had refused to "take upon myself the responsibility of sanctioning" the compromise, and had insisted that agreement must wait for the meeting at the Commons, it is clear that it was not until he returned to Newcastle that Buddle discovered that the United Committee were hostile to the arrangement agreed in London. ${ }^{55}$

But it is also clear that both Ashley and Lambton were suffering under misapprehensions as well. Ashley's letters clearly indicate that he did not distinguish between "the gentlemen connected with the coal-trade" and the MPs for Northumberland and Durham whom he had met at the Commons. The Prime Minister shared this confusion. "The part taken by the majority of Members of the House of Commons connected with the Coal Trade District of Northumberland and Durham", Peel told Lord

52 Buddle to Londonderry, 9 July.

53 Buddle to Ashley, 5 July (2 letters), National Coal Board Manuscripts I/JB/1797-98.

54 Ashley to Buddle, 8 July, ibid., 1799.

55 Buddle to Ashley, 11 July (draft), ibid., 1804. 
Londonderry, "led me to infer that the bill did not meet with much opposition in that district."56 Buddle, in consulting with the MPs while acting on behalf of the United Committee, cannot have helped to remove such misunderstandings. Lambton, however, was clearly wrong when he assumed that, because his fellow MPs had agreed, that agreement was binding on all. His brusque suggestion that other mining areas could have sent their own deputations "if they chose" 57 (a step later adopted by South Staffordshire, whose representatives Ashley found "very positive, very unreasonable" 58) implies that he was at least aware of other parties. Moreover he and Buddle had both attended a meeting at the Home Office on the day subsequent to their meeting with Ashley, at which Ainsworth had stated that the compromise agreed the previous day, if put into effect, would "stop his colliery", and "he was therefore bound to oppose the bill". 59

If Buddle felt he was not bound by the agreement, clearly Londonderry, who had been no party to it, was not bound either, and his presentation of the petition certainly did not worry Ashley. Lord Clanricarde was, in fact, correct when he said that "no doubt the understanding was that, with certain concessions, the bill would be passed with the support of those present", and Londonderry equally correct when he said that "there appeared to have been some mistake, and no doubt it was an unfortunate one". ${ }^{60}$ Certainly there is no more justification for Professor MacDonagh's unsubstantiated allegation that Londonderry "denied, and induced Buddle to support him in denying" that the meeting with Ashley had produced a binding agreement, than there was for the Hammonds' charge that Londonderry's conduct was an act of bad faith. ${ }^{61}$ If anyone showed bad faith in the arrangement, it was the Yorkshire coal-owner, Lord Wharncliffe. He had been present at the House of Commons meeting, but subsequently approached Ashley to ask him to postpone all except the female clauses of the bill - which Ashley "positively refused" 62 - and, in spite of Graham's assurances in the Commons of general government support, Wharncliffe (as President of the Council) adopted a largely hostile

56 Peel to Londonderry, 22 July, Peel Papers, loc. cit., ff. $71-72$.

57 Hansard, LXIV, c. 426.

58 Ashley's diary, 28 June, loc. cit., p. 428.

59 Buddle's place-book, 21 June, pp. 158-60.

60 Hansard, LXV, cc. 104, 120-22.

61 O. MacDonagh, "Coal Mines Regulation: The First Decade, 1842-1852", in: Ideas and Institutions of Victorian Britain, ed. by R. Robson (London, 1967), p. 62; J. L. and B. Hammond, Shaftesbury, p. 79 , note 2.

62 Ashley's diary, 2 July, loc. cit., p. 429. Hedworth Lambton held Wharncliffe culpable, cf. his letter to Ashley, Hansard, LXV, cc. 1096-97. 
line in the Lords. Whatever the rights and wrongs of the compromise, the only ultimate effect was Matthew Bell's failure to present the Northern Coal Trade's petition with which he had been entrusted to the Commons. That House, with the support of "Bell and his Northern gentry", ${ }^{63}$ passed the bill as amended, only to see the Lords defeat the agreed provisions. ${ }^{64}$

Ainsworth believed that those who supported Ashley's compromise represented only areas where the seams of coal were thick. ${ }^{65}$ Certainly Thomas Crawford, viewer to Lambton's Littletown and Sherburn collieries in County Durham, thought that "the seams in this county are not one in a hundred less than three feet in depth", ${ }^{66}$ while a similar claim, though disputed by the Children's Employment Commissioners, was made for the Tyneside collieries. ${ }^{67}$ Sub-commissioner Mitchell believed that the thickness of the Hutton seam in the North-East was "the most complete security that young children are never employed, nor can be profitably employed, to bring the coals from the workings to the horseways". ${ }^{88}$ Ainsworth, on the other hand, complained that "those who had to work their mines could not but object to the practice of boys labouring only three days a week", ${ }^{69}$ for, as he explained to the Home Secretary, "it required two small boys to each collier to carry away the coals from him in whickets in his thin seam". ${ }^{70}$ Lord Londonderry read to the Lords a statement from the Yorkshire coal-owners, in which they claimed boys aged between eight and fourteen were essential "in the thin coal mines", because the underground roadways could not be made sufficiently high for adults "without incurring an outlay so great as to render the working of such mines unprofitable". ${ }^{71}$ The Commissioners, too, seemed to endorse these sentiments, when they wrote of the thin-seamed pits that it was "impossible by any outlay compatible with profitable returns to render such coal mines [. . ] fit for human beings to work in". ${ }^{72}$

As Ainsworth admitted at the Home office, whatever sentiments might be expressed about potential unemployment, the chief worry was that owners would be forced to close pits. But there was also another feeling at

63 Ashley's diary, 23 June, loc. cit., p. 426.

${ }^{64}$ On the "compromise", see Taylor, "The Third Marquess of Londonderry", p. 24, and Heesom, "Entrepreneurial Paternalism", p. 242.

65 Buddle's place-book, 21 June.

66 CEC, First Report, pp. 68-69.

67 Ibid., pp. 59-60.

68 Ibid., Appendix, Pt I, p. 143.

69 Hansard, LXIV, c. 1000.

${ }^{70}$ Buddle's place-book, 21 June.

71 Hansard, LXIV, c. 545, note.

72 CEC, First Report, p. 271. 
work, besides this naked self-interest, which provoked the coal trade to resist both the proposed minimum age of thirteen, and the subsequent proposal of alternate day's working accepted by Ashley for ten-tothirteen-year-olds. When Ashley announced his agreement to the alternate day scheme, he added that "he trusted that the time thus granted in boyhood would be devoted to the purpose of moral and religious improvement." He was at once answered by Ainsworth: "it was said, the children must be educated, but who was to pay for their education?"73

When moving for the establishment of the Children's Employment Commission in 1840, Ashley had proclaimed that his first "grand object" was "to bring these children within the reach of education. It will be time enough then", he added, "to fight about the mode." supporters clearly thought that the establishment of the principle of alternate day working was enough; "fair opportunities for education could not be obtained without the indulgence of the alternate days", Brotherton told the Commons, ${ }^{75}$ but the coal-owners sought rather more practical answers. The Yorkshire coal-owners painted a bleak picture.

The whole of a collier's family under thirteen years old will, if turned out of the pits, be entirely dependent on the scanty earnings of the parent for food, clothing, and instruction. Those earnings alone are barely sufficient to procure even food for their children, without mentioning wearing apparel and education. What, then, will be the probable condition of the children under thirteen years of age after the passing of Lord Ashley's bill? [...] Prevented by the Legislature from working in the mines, and unable to pay for daily instruction [...] they would grow up in a state of physical and moral destitution. ${ }^{76}$

Buddle believed that if children were kept out of the pits "their parents being able to send them to school will be out of the question - even supposing them to be willing", ${ }^{77}$ and the apparent unwillingness of parents was universally admitted. E. D. Protheroe, MP for Halifax, for instance, told the Commons that at the schools in the Forest of Dean "attendance could not be obtained without pursuing almost a system of persecution". ${ }^{78}$ Sub-commissioner Symons, who felt the "only mode" of securing education was "the legal enforcement of their regular attendance at proper schools", ${ }^{79}$ found a surprising ally in John Buddle, who thought some plan

${ }^{73}$ Hansard, LXIV, cc. 426-27.

${ }^{74}$ Ibid., LV, c. 1274.

75 Ibid., LXIV, c. 427.

${ }^{76}$ Ibid., cc. 545-56, note.

${ }^{77}$ Buddle to Lambton, 28 May.

${ }^{78}$ Hansard, LXIII, cc. 1363-64.

${ }^{79}$ CEC, Appendix to First Report, Pt II, p. 193. 
must be devised for educating the children "free of cost to themselves, and rendering their attendance at school compulsory" ${ }^{80}$ But compulsory education, as Parliament was to discover the following year, with the Factory Education bill, was fraught with difficulties. As George Elliott, a County Durham viewer, put it, anticipating the subsequent furore, "a very great number of pitmen are dissenters", who would "most decidedly object to allowing their children to go to the established church". 81

The role of coal-owners in the field of education has been discussed elsewhere. ${ }^{82}$ Hedworth Lambton believed it was the duty of the coalowners to provide schools, and pointed to the example of his late brother; ${ }^{83}$ Londonderry provided schools, and was to provide more $;{ }^{84}$ Fitzwilliam's schools were singled out for special commendation by sub-commissioner Symons; ${ }^{85}$ Lord Francis Egerton's schools were described as "excellent"; 86 the Duke of Sutherland, although himself no longer directly involved in the coal trade, tried to persuade Lord Brougham to support the idea of education on alternate days; ${ }^{87}$ and Lord Hatherton believed the promotion of education to be "a paramount object". ${ }^{88}$ There was, of course, resistance to education, too. Nicholas Wood, of Hetton Colliery, believed that education "would not benefit the men and the boys as work-people", as their work was "merely mechanical", and he was perhaps thinking of his colleague Buddle when he added that many viewers thought the pitmen would be "worse workmen if educated, as education would produce a dislike to work". ${ }^{89}$ Buddle's own laconic comment was that "the labour of the pen is already more pentiful than that of the pick."

Where a pitman's boy is kept at school till he is thirteen or fourteen and can write a legible hand and has reached the golden rule in arithmetic, Daddy then looks on him as a scholar, and thinks it a shame to send sic a lad [sic] to the pit, and he seeks about for a clerk's place for the lad, to his great loss and inconvenience, and in ninety-nine cases out of one hundred does not succeed. In the mean time he is not able to keep the lad at school, who runs

80 Buddle to Lambton, 28 May.

81 CEC, Appendix to First Report, Pt I, p. 660.

82 R. Colls, "'Oh Happy English Childeren!': Coal, Class, and Education in the NorthEast", in: Past \& Present, No 73 (1976), pp. 75-99; A. J. Heesom, "Coal, Class and Education", ibid., forthcoming.

${ }^{83}$ Hansard, LXIII, c. 1354.

${ }^{84}$ Heesom, "Entrepreneurial Paternalism", pp. 247-49.

85 Mee, Aristocratic Enterprise, op. cit., p. 142.

86 CEC, Appendix to First Report, Pt II, p. 194.

87 E. Richards, "The Industrial Face of a Great Estate: Trentham and Lilleshall, 1780-1860", in: Economic History Review, Second Series, XXVII (1974), p. 428.

88 Hansard, LXV, c. 111.

89 CEC, Appendix to First Report, Pt I, p. 428. 
about and acquires habits of indolence which generally ends in his becoming a vagabond and [...] a thief. All this requires much more consideration than the most drastic advocates for education, in the heat of their zeal, are disposed, or even capable, of giving the subject.

"Far too big a cry and fuss is made about education", Buddle concluded. ${ }^{90}$

Regardless of the question of education, some connected with the coal trade believed that young children should be kept out of the pits. John Twibell, a Barnsley coal-master, believed that children under ten should not be employed, and perhaps was one of those whom Francis Egerton believed needed the extra push provided by legislation, since he told the sub-commissioner that he was considering making the exclusion of under-tens "a rule" in the future. ${ }^{91}$ Egerton's own Bridgewater collieries, managed by James Loch, had already prohibited boys under ten, and sub-commissioner John L. Kennedy believed that a feeling against employing very young children was "rapidly gaining ground throughout the district". ${ }^{2}$ William Goodinson, Fitzwilliam's underground steward at Elsecar, believed it would be quite possible to dispense with the work of children "till they were eleven years old", and thought the invention of a mechanical device to replace the trapper boys was a practical proposition. ${ }^{93}$

Londonderry, on the other hand, told Buddle that "he would advocate nine as the proper age for sending boys to be trappers". To the Lords he said he thought boys were "as fit for the work at the age of eight as they were at ten".94 The Lords, however, accepted the age of ten as the minimum; and Lord Devon, whom after much difficulty in finding a sponsor Ashley had prevailed upon to move the bill in the Lords, also consented to abandon the proposal for alternate day working. The coalowners thus secured what sub-commissioner Mitchell had recommended. Mitchell himself had favoured restriction to twelve, and had expressed his approval of George Elliott's testimony, that "the most salutary results would be produced from an enactment prohibiting children from going into the pit before the age of twelve"; Elliott, however, had added that "until that period" it was necessary to provide "cheap education". In the absence of such education, and "looking also at the necessities of poor parents with large families, and of poor widows", as well as the necessity of

90 Buddle, "Comments on Ashley's Speech".

91 CEC, Appendix to First Report, Pt I, p. 259; Hansard, LXIII, c. 1355.

92 CEC, Appendix to First Report, Pt Il, p. 152.

93 Ibid., Pt I, pp. 242-43. The pitmen argued that mechanical ventilation was unsafe, and a mere device "to save the masters a few paltry shillings in wages", R. Fynes, The Miners of Northumberland and Durham (Wakefield, 1971), p. 59.

94 Buddle's place-book, 21 June; Hansard, LXV, c. 120. 
providing labour, Mitchell concluded that he had to agree with "those who consider ten years of age as the proper time when children should be allowed to go to work in the collieries". ${ }^{55}$

When he introduced his bill, Lord Ashley had praised the Children's Employment Commissioners for discharging their duty with "unrivalled skill, fidelity, and zeal". ${ }^{96}$ But if there was one thing more than another upon which those who opposed (or even had doubts about) Lord Ashley's bill were agreed, it was that the report of the Commissioners was not to be trusted. The celebrated petition from the Northern Coal Trade which Londonderry presented to the Lords was not, as Henry Morton explained to Hedworth Lambton, part of a plan to "oppose Lord Ashley's bill as arranged by you and others in London", but rather "a remonstrance drawn up by the coal owners more to vindicate themselves against the allegations made by the Commissioners, to satisfy the public of their unfounded nature". ${ }^{97}$ Londonderry was the most vicious against the report; the Commissioners and sub-commissioners were not "at all competent to give their Lordships correct impressions; they were not people of the calibre to do it", he said, and "the evidence was so full of mistakes that it was impossible their Lordships should give full credit to it." 98 Hatherton, while denying that the report was false, and, unlike Londonderry, who repeatedly attempted to impugn the Commissioners themselves, refusing to cast any aspersion on the "strict rectitude, honour, and sincerity of the commissioners", nevertheless believed that "entire credence ought not to be given to this report". ${ }^{99}$ When the Bishop of Norwich praised the accuracy of the report, Hatherton replied that "great excitement" had been caused among the mine owners "in consequence of the very exaggerated and overcharged statements" contained in the report. Some of these statements, he said, he could "contradict from his own knowledge". Many of the remarks in the report ranked among "the most unjust, the most partial, which had ever been submitted to Parliament as the ground of any legislative measure". ${ }^{100}$

Even the Duke of Wellington added his influential voice in criticsm. In the early days of discussion on the bill, Wellington had suggested to

95 CEC, Appendix to First Report, Pt I, pp. 132-33.

96 Hansard, LXIII, c. 1321.

97 Morton to Buddle, 27 June, National Coal Board Manuscripts I/JB/1792.

${ }^{98}$ Hansard, LXIV, cc. 538-39; Morning Post, 25 June; Hansard, LXV, cc. 6-7.

${ }^{99}$ Hansard, LXV, cc. $111,117$.

${ }^{100}$ Ibid., LXIV, cc. 1166-68. 
Londonderry that he procure some official document that would show "the real state of the case regarding the working of females and children in the collieries", ${ }^{101}$ a suggestion which resulted in Londonderry's request to Brandling for the Northern Coal Trade petition. ${ }^{102}$ On July 8, in the House of Lords, Wellington made his hostility to the bill public, much to the delight of John Piele, Lord Lonsdale's viewer (who noted that "the old Duke of Wellington is taking the subject in hand properly"), ${ }^{103}$ and much to the disgust of Lord Ashley, who recorded in his diary:

the Duke of Wellington [...] spoke with contempt and suspicion of the Commissioners. I could not guess at his motive, unless it were an attack on the late Government. And this, after he had told me ten days ago at Buckingham Palace that he entirely approved my speech, and that "the House or Lords would give us no trouble!" nay, more, in a letter I received from him still later, he assured me that "he should take the same line in the Lords as the Ministers had taken in the Commons!"104

On the second reading of the bill in the Lords, Wellington, while admitting that "the report had made a great impression" on his mind, nevertheless asserted that "the evidence was not exactly of the nature which ought to carry with it their Lordships' full confidence", and suggested that the House should proceed to further inquiries of their own before they risked legislation based upon such doubtful materials as "the volumes of evidence which they had before them". ${ }^{105}$ Not surprisingly, Ashley did not share Wellington's enthusiasm for what the House of Lords had done to the bill. ${ }^{106}$

Criticism of the report was not confined to the Lords, however. In the Commons Lambton thought there had been "some exaggeration" by subcommissioner Leifchild, who investigated Northumberland and North Durham; Robert Scott, MP for Walsall, complained of inaccuracies in James Mitchell's report on the Midlands; Ainsworth claimed many cases in the reports were "highly coloured", and called attention to one alleged interview which, he said, no one could recall having taken place; C. P. Villiers, MP for Wolverhampton, thought "there was reason to believe that the reports of the commissioners were, in many instances, somewhat partial and inaccurate", and received support from Matthias Attwood, MP for

101 Wellington to Londonderry, 12 May, Londonderry Manuscripts 113 (202).

102 Londonderry to Brandling, 28 May; Coal Trade United Committee Minutes, 1840-44, 30 May, p. 169.

103 Piele Sen. to Buddle, 12 July, National Coal Board Manuscripts I/JB/1805.

104 Ashley's diary, 8 July, loc. cit., p. 430.

105 Hansard, LXV, cc. 116-17.

106 Ashley's diary, 1 August, quoted in G. Best, Shaftesbury (London, 1964), p. 105. 
Whitehaven, who claimed that sub-commissioner Symons had "made a report which he was not warranted in making" on Cumberland. W. R. C. Stansfield, MP for Huddersfield, singled out sub-commissioner Kennedy for attack, claiming that "through inadvertence or neglect" the evidence produced by the Commissioners had been "perverted". 107

Outside the House, colliery agents were working hard to contradict the Commissioners' findings. John Robson, manager of Whitwell colliery, and viewer at Hetton, told Buddle that he could send him evidence of "the real state [...] of the working classes in collieries", which would "satisfy any person, however zealous in the cause, and give a widely different impression from that which I gather from the report and accompanying evidence" ${ }^{108} \mathrm{John}$ Piele from Whitehaven complained that in his isolated location he was cut off from any efforts to contradict Ashley, but nevertheless professed himself "desirous to join any proceedings that can be useful", while his son sent Buddle statistical lists from Lord Lonsdale's collieries which, he claimed, would give the "lie direct" to the subcommissioners" statements, and added that he could get similar lists "from each colliery in West Cumberland". ${ }^{109}$ John Buddle furnished reports to Hedworth Lambton on what he said was the true state of some of the North Durham pits, ${ }^{110}$ and himself denounced much of the Commissioners' report as the result of mere gullibility, suggesting that the subcommissioners had been "imposed upon" by "mendacious characters". How, he asked, could they have been so weak as to believe such improbable stories; "yet the collective wisdom vociferated hear, hear!!"111

One of the chief complaints from owners and viewers was that the working men, women and children had been consulted by the Commissioners in preference to themselves. If the Commissioners had been sent to get information, said Ainsworth, "they ought at once to go to the fountain-head", ${ }^{112}$ while Londonderry said that "those persons who were most competent to give opinions had not been examined, for none of the overmen or viewers had been examined." 113 Instead, the subcommissioners had interviews "artful boys and ignorant young girls", and put questions "in a manner which in many cases seemed to suggest the

107 Hansard, LXIII, cc. 1354-55; LXIV, cc. 424, 1000-07.

108 Robson to Buddle, 11 July, National Coal Board Manuscripts, 1/JB/1803.

109 Piele Sen. to Buddle, 12 July; Piele Jun. to Buddle, 12 July, National Coal Board Manuscripts I/JB/1805.

110 Returns of the ages of the pitmen in the Londonderry collieries, ibid., 1790; Hansard, LXIII, c. 1355.

111 Buddle, "Comments on Ashley's Speech".

112 Hansard, LXIV, c. 1000.

113 Ibid., LXV, c. 581. 
answer"; in short, they had behaved in "anything but a fair and impartial mode". 114

The reason for the sub-commissioners' behaviour is easy to find. As the Commissioners wrote in their report on the West-Riding,

\begin{abstract}
While the evidence is [. . .] overwhelming, that in this district children are to be found in the coal mines regularly at work at the ages of five, six, and seven, it is clear, from a careful perusal of the whole of the depositions, that this fact could never have been brought to light by the examination of the coal owners only. It is in general with extreme reluctance that this class of witnesses acknowledge that children begin to work in the pits even as early as seven years of age. With [. . . ] few exceptions [. . .] the evidence uniformly given by the coal owners would indicate that they are ignorant of the extremely early ages at which children may be found working in their mines. The same remark is applicable to the tenor of the evidence given by the underground stewards and other agents. ${ }^{115}$
\end{abstract}

Attwood censured sub-commissioner Symons for suggesting that, if the men had been interviewed privately, rather than in the presence of the viewers, they might have been more forthcoming, but though Attwood claimed that the viewers and managers only wished to given "the most explicit information" the probability is that Symons was justified. ${ }^{116}$ Lord Ashley, at least, had no doubt that "the evidence of the workpeople themselves is worth more than all the rest", because they alone knew the extent of their sufferings. "I have ever found their statements more accurate", he claimed, and had "never met with any attempts to mislead in the evidence given by working men of their own condition". ${ }^{117}$ The Morning Chronicle, whose support Ashley believed to have been "most effective", concluded that, though the view of the children in the collieries of Tyne and Wear given by Lord Londonderry differed from that of the Commissioners, "we would rather take the evidence of a disinterested than of an interested person on the subject."118

Londonderry, however, was not sure how disinterested the Commissioners, in fact, were. "These gentlemen", he said "come to this inquiry fresh from the factory commission, with all the prejudices that that commission was likely to excite, and with an expectation and desire of finding similar oppression amongst the miners to those which they had

114 Ibid., LXIV, c. 539; CEC, Appendix to First Report, Pt I, p. 525, where Leifchild denies having asked leading questions.

115 CEC, First Report, p. 25.

116 Ibid., Appendix, Pt I, p. 307; Hansard, LXIV, cc. 1005-06.

117 Hansard, LXIII, c. 1328.

118 Morning Chronicle, 7 May; Ashley's diary, 14 May, in Hodder, op. cit., p. 418. 
found among the manufacturing population." 119 The following year, after the abortive Factory Bill, Edward Baines claimed that it had been the aim of the Children's Employment Commissioners "to search out whatever was defective or wrong in the physical, social, or moral state of the children in the mining and trading districts, and who, in the discharge of their duty, mainly (I do not say exclusively) inquired into and recorded all that was evil and that needed correction." It was obvious, Baines concluded, that "the Commissioners have a strong temptation to make out a case, - to bring home a full budget". ${ }^{120}$ Certainly the Commissioners themselves were men of strong opinions, and Ashley thought that two of them at least, Horner and Saunders, were his "warm" supporters. ${ }^{121}$ Some of the subcommissioners, however, were less self-confident. J. C. Symons admitted that he may have been "submitted to false evidence", though believing his depositions from Yorkshire to be "on the whole a fair representation." 122 With only a fortnight in Cumberland, he complained that he could only report on the "prominent features". ${ }^{123}$ Sub-commissioner Kennedy conceded that he had difficulty in eliciting the truth from the pitmen in Lancashire, ${ }^{124}$ and Leifchild was aware of possible deficiencies in his evidence on Northumberland and Durham. Even when he was able to master what was virtually a foreign language ("an interpreter being inadmissible"), Leifchild encountered "ignorance, obstinacy, doubts and suspicions" from his witnesses, which made it difficult for him to get at the facts. ${ }^{125}$ As he confessed to Buddle, he was "necessarily ignorant" of the subject, and his ultimate report was "most imperfectly developed". ${ }^{126}$

In one point, though, the accuracy of the evidence does seem to have been questionable. The Children's Employment Commission report was illustrated with drawings made, or in some cases commissioned by, the sub-commissioners. Stansfield protested at this "indecent mode of attracting attention" and thought it was likely to lead to "great exaggeration", ${ }^{127}$ while Londonderry thought the pictures, which he found "extravagant and disgusting", in some cases "scandalous and obscene", were not such as should appear in a "grave publication". Londonderry believed their pur-

119 Hansard, LXIV, c. 579.

120 E. Baines, Jun., The Social, Educational, and Religious State of the Manufacturing Districts [. . . ] in Two Letters to Sir Robt. Peel (London, 1843), p. 6.

121 Ashley's diary, 3 March, loc. cit., p. 409.

122 CEC, Appendix to First Report, Pt I, p. 173.

123 Ibid., p. 307.

124 Ibid., Pt II, p. 182.

125 Ibid., Pt I, pp. 524-26.

126 Leifchild to Buddle, 18 May, National Coal Board Manuscripts I/JB/1783.

127 Hansard, LXIII, c. 1006. 
pose was "more calculated to excite the feelings than to enlighten the judgement", ${ }^{128}$ and recent research has suggested that they were, indeed, highly successful propaganda illustrations rather than, as they appeared, drawings from life. ${ }^{129}$ Southwood Smith and his colleagues on the Commission doubtless felt themselves justified; but the owners, in this case, at least, with authority, felt themselves equally justified in their doubts about the validity of the evidence. Both owners and Commissioners sincerely believed in the correctness of their own evidence of conditions in the mines, but the fairest statement on this aspect of the report probably came from Lord Wharncliffe's son, Stuart Wortley, MP for Halifax.

He could not say, nor could any man say, that in the report, here and there, some exaggerated statements could not be found, but that these were exaggerations which affected the conclusions which his noble friend [Ashley] had come to, he did not believe. ${ }^{130}$

\section{IV}

One of the chief reasons for casting doubt on the report was to secure delay in passing legislation based upon it. C. P. Villiers vehemently defended those who supported Ainsworth's attempts to postpone discussion; the reason was not to condone "the abuses which the coal owners of the north had permitted, to their disgrace, to exist in their collieries", but "in order that the truth might be accurately ascertained before any legislation was adopted on the subject". ${ }^{131}$ Londonderry asked that "time should be given to collect impartial evidence", because important legislation "should not be hurried through Parliament". He reminded the House of Lords that the aim of the Northern Coal Trade petition was "not to prevent any interference which humanity rendered essential", but "to prevent any rash and hasty alterations", and "not to legislate until the present excitement had been allowed to subside". ${ }^{132}$ Privately he was prepared to acknowledge to Buddle that his motive for pressing for a select committee on the bill was simply as a device to thwart its passage, ${ }^{133}$ but even allowing for his total 128 Ibid., LXIV, c. 539.

129 Celina Fox, "The Development of Social Reportage in English Periodical Illustration during the 1840s and Early 1850s", in: Past \& Present, No 74 (1977), pp. 94-99. Subcommissioner Kennedy said one of his illustrations was to "convey to others impressions similar to those which ocular inspection had given to myself", CEC, Appendix to First Report, Pt II, p. 159.

${ }^{130}$ Hansard, LXIII, c. 1360.

131 Ibid., LXIV, cc. 1003-04.

132 Ibid., LXIV, cc. 540-42; LXV, cc. 101-02, 118-19.

133 Londonderry to Buddle, 13 July, National Coal Board Manuscripts I/JB/1807: "If I cannot throw over the bill the Select Committee will with good management put an end to it for this session at least." 
opposition to the bill there was some justification for Lord Radnor's statement that the bill was being pushed through at "railroad speed". ${ }^{134}$

In introducing his bill, Ashley had announced that since an "enormous mischief" had been discovered, an "immediate remedy" would be proposed. ${ }^{135}$ Privately in his diary he had already complained at "repeated delays" in bringing in his bill, and requests from the Government for postponement merely served to confirm his belief in their hostility; but he pledged that "I shall yet see that the harvest is retarded, not denied." 136 It was not only the coal-owners, though, who felt that legislation was being pressed too rapidly. Lord Devon, the bill's sponsor in the Lords, confessed that if the bill had come on earlier in the session he would have been willing to move for a committee of inquiry himself into the time that children under thirteen should be employed, as well as on "some other points on which parties concerned in collieries had a good deal to say", and confessed that "there was not sufficient evidence to enable him to say with perfect confidence" that a certain clause would not operate injuriously. ${ }^{137}$ Most surprisingly of all, there is even evidence that Ashley was prepared, at one time, to consider delay. On 6th June Buddle wrote to Londonderry to tell him that the executive committee of the Northern Coal Trade had received letters from Matthew Bell and Hedworth Lambton, stating that they had been in communication with "Lord Ashton [sic]" on the subject of his intended bill. Ashley, they reported, only intended to legislate on the subjects of "the limitation of the age of the pit lads" and "the number of hours to the day's work. But", they added, "he does not mean to press for a decision upon it this session in order to allow time for due consideration." Buddle thought this decision to be "judicious", ${ }^{138}$ and Hedworth Lambton, too, believed that, in legislating on the coal mines, the Commons "must be most careful to do so cautiously and temperately". 139

And in one point the bill's opponents were able to show that the legislation was over-hasty. The bill proposed inspectors to see that the provisions of the law were carried out. On his copy of the bill, Londonderry wrote a note to his solicitor, John Gregson, asking "is there any power here to compel the coal owner, lessee, or agent to send the inspector or let him go

134 Hansard, LXV, c. 114.

135 Ibid., LXIII, c. 1321.

136 Ashley's diary, 21 May - 1 June, loc. cit., pp. 419-20.

137 Hansard, LXV, c. 109.

138 Buddle to Londonderry, 6 June, Londonderry Manuscripts 142 (1297). The executive-committee minutes have not, apparently, survived before January 1842 , so Buddle's statement cannot be corroborated, but there is no reason to suppose he would have invented it.

139 Hansard, LXIII, c. 1354. 
down the pit? Suppose", he asked, "the coal agent refused to send him down and give him candles \&c., and facilities below, how could the coal owner be punished?" Gregson replied that he thought the inspector would be entitled to all facilities to enable him to perform his duties, and the agent or owner "would be liable to indictment for refusing him". ${ }^{140}$ Londonderry, however, disregarded Gregson's opinion. When the third reading of the bill came on in the Lords, he pointed out, "to show the haste with which it was framed", that the clause empowering inspection was "absolutely inoperative". If the bill passed in its present shape, Londonderry announced, he was quite prepared to say to an inspector: "You may go down the pit, and when you are down, you may remain there." ${ }^{141}$ Londonderry has been condemned for this remark, which, so it is claimed, had precisely the opposite effect from that which he intended, ${ }^{142}$ but, as he pointed out, "the supporters of the measure ought [ . . ] to give him credit for [... lending his aid towards its amendment", for, as he told the Lords, "he had preferred pointing out this defect to telling the coal owners of the north, and of Scotland, which he might have fairly done, that the bill was inoperative". Lord Campbell, a former Attorney-General, agreed with Londonderry's reading of the bill; as a supporter of the bill, Campbell regretted that it was "defective in this respect", and it was left to Londonderry's fellow coal-owner, Wharncliffe, to propose the necessary amendment. ${ }^{143}$ Triumphantly, Londonderry noted on his copy of the bill: "Mr. Gregson's opinion turned out wrong and mine right; see Lord Campbell's speech." 144 If Lord Redesdale was right in his suggestion that Londonderry would not be willing to "brave the inference which would be drawn from throwing any difficulties in the way of inspection", Londonderry was equally right when he said this clause was an example of "clumsy legislation". 145

Inspection was contentious for other reasons, however, beyond poor draftsmanship in the bill. On the recommittal of the bill in the Lords, Londonderry proudly boasted that "the only clause which stood the same

140 Printed copy of the Mines Bill with manuscript additions, National Coal Board Manuscripts $1 / \mathrm{JB} / 1815$.

141 Hansard, LXV, c. 891.

142 R. Challinor and B. Ripley, The Miners' Association: A Trade Union in the Age of the Chartists (London, 1968), pp. 212-13.

143 Hansard, LXV, cc. 891-92.

144 Printed copy of the Mines Bill etc., 1815.

145 Hansard, LXV, c. 892. Ashley protested that subterranean inspection was "altogether impossible; and indeed, if it were possible, it would not be safe. [.. .] I for one should be very loth to go down the shafts for the purpose of doing some act that was likely to be distasteful to the colliers below", ibid., LXIII, c. 1340. 
was that relative to Government inspectors." Wharncliffe said there would be no objection to inspection, but Londonderry, claiming with some justice to be the authentic "organ of the coal owners on the North", disagreed. He produced a resolution from the United Committee, thanking him for his exertions on their behalf, but asking that he urge on the Lords the "entire omission" of the clause on inspectors. ${ }^{146}$ The clause as originally proposed had stated that each inspector

shall report his proceedings in the execution of this Act in such manner as may be directed by the Secretary of State; and he shall in like manner report the state and condition of the mines and collieries he shall inspect, and of the persons working therein, and whether or not the provisions of this act are properly observed.

Londonderry's first idea was to omit the reference to the "state and condition of the mines", but leave the inspector to report on the miners. Under prompting from Buddle, though, he went further, and proposed simply that the inspector

shall report his proceedings in the execution of this Act in such manner as may be directed by the Secretary of State; and he shall in like manner report whether or not the provisions of this Act are properly observed.

This amendment, as altered by Wharncliffe, was accepted. ${ }^{\mathbf{1 4 7}}$

Buddle was probably responsible for the Northern Coal Trade's resolution against inspectors. On a copy of the bill (possibly that which the Coal Trade forwarded to Londonderry, to which he referred in the Lords' debate ${ }^{148}$ ) Buddle noted that "the men employed in collieries are generally very ignorant and are subject to be very strongly excited by trifling and apparently inadequate causes". Therefore, he concluded, "unless the inspectors were persons perfectly acquainted with their habits and feelings, they might (although quite unintentionally) produce by their interference the most disastrous consequences." 149 This fear, at least, was shared by the Home Secretary, who worked himself up into "a great state of alarm" when the man appointed as the first mines inspector, Seymour Tremenheere, actually talked over their grievances with the striking pitmen in $1844 !^{150}$

Londonderry's own fears went beyond the possibility of the stirring up of

146 Ibid., LXV, cc. 578-79, 587-88; Morning Post, 26 July.

147 Coal Trade United Committee Minutes, 1840-44, pp. 178-79; printed copies of the Mines Bill with manuscript additions, National Coal Board Manuscripts I/JB/1815-16.

148 Hansard, LXV, cc. 579-80.

149 Printed copy of the Mines Bill etc., 1816.

150 R. K. Webb, "A Whig Inspector", in: Journal of Modern History, XXVII (1955), p. 359. 
agitation, however, and so he was not, as his first suggested amendment indicates, so keen to prevent the inspector's contact with the pitmen as his agent. Of more immediate concern to Londonderry and some of his fellow owners was the threat which the inspectorate posed of a sort of licensed espionage. Even Lord Wharncliffe, who favoured inspection in general, feared that they might be authorised "to inquire into the management of many things about which they had no business". ${ }^{151}$ When Tremenheere had taken up his appointment, he recorded that on numerous occasions he had asked permission from owners and agents to see colliery plans, and to receive explanations of different systems of working, and had been "struck with the marked difference in point of care and skill very frequently shown in the management of adjoining collieries". It appeared, he said, that there was little interchange of information between managers, and advanced the following explanation:

The competition of trade appears naturally to produce a reluctance to communicate, or a delicacy in inquiring into what is done by a neighbouring proprietor. Jealousies may exist as to the superior plans of one engineer being imparted to another. The man of greater intelligence may, perhaps, justly conceive that, as his knowledge and skill are the source of his livelyhood, he is not called upon gratuitously to divulge them. ${ }^{152}$

And what was true of individuals was also true of the great colliery enterprises of the North.

When John Buddle had replaced Arthur Mowbray as chief viewer of the Vane-Tempest collieries (when Londonderry, then Lord Stewart, had married the heiress), Mowbray had taken his knowledge off to the rival Hetton Coal Company. Twenty years later this was still a source of complaint to Londonderry, who warned Buddle, after the dismissal of a fitter at Seaham, that "care must be taken, as in Mowbray's case, that the knavish malcontents and delinquents in leaving our concerns do not revenge themselves by information or means derived from our employ."153 When Buddle himself quarrelled with Londonderry in 1841, and the latter threatened to bring in an independent accountant to check the books, Buddle wrote to the trustee of the estate, Edmund McDonnell, that before he did so Londonderry should "consider what the consequences of exposing the situation and power of the collieries thus may be, in the position they hold in the trade as compared with Lambton's new collieries and

151 Hansard, LXV, c. 587.

152 Fourth Report from the Commissioner appointed under the Provisions of the Act 5 \& 6 Vict., c. 99 [PP, 1847, XVI], pp. 428-29.

153 Londonderry to Buddle, 28 January 1839, Londonderry Manuscripts 142 (1171). 
Hetton." ${ }^{154}$ Fear of exposing the true state of the concern to rivals persisted after Buddle's death. In 1844, when a proposal was advanced to establish a central repository of colliery plans, Buddle's successor, George Hunter, wrote to Londonderry that it would "show the country at large all your colliery plans - areas of coal worked and unworked - in fact it is neither more nor less than a power given to some people to come to your colliery offices and take such documents from us as they see fit." And he concluded: "it will be the most impertinent and troublesome affair to the collieries, indeed worse than Government inspectors." 155 The following year Londonderry himself complained that summonses had been issued to examine all his colliery books and papers in order to fix a new county rate, and appealed to the Home Secretary to prevent such a search, unless accompanied by a secrecy similar to that imposed on the Income Tax Commissioners. ${ }^{156}$ With this fear of disclosing trade secrets in the intense competition of the early-nineteenth-century coal trade, it is hardly surprising that Tremenheere experienced difficulties in eliciting information, or that the owners should have opposed the establishment of an inspectorate in the first place.

The Earl of Radnor objected to Lord Ashley's bill "because he objected to interference with the market of labour". ${ }^{157}$ Radnor's was the most thorough-going laissez-faire approach to Ashley's bill, with the coal-owners, on the whole, contenting themselves with asking where the process of intervention was to end. When the chimney-sweeps bill had been introduced in 1840, Londonderry had warned the Lords that they would soon have to bring in another bill "to arrest the employment of children in all the other public works of the country". ${ }^{158}$ Now Fitzwilliam urged that "they ought not to confine their inquiries to collieries, but to take a comprehensive view of the effect of labour upon those engaged in other branches of industry." 159 Lord Brougham, in a carefully reasoned speech (which both Londonderry and Devon, from their different points of view, interpreted as offering support for their cause), summed up the dilemma facing the House, the tightrope of contemporary economic thinking that

154 Buddle to McDonnell, I June 1841, Buddle Letter Book, No 30, Buddle Manuscripts, Vol. 24.

${ }_{155}$ Hunter to Londonderry, 15 December 1844, Londonderry Manuscripts 149 (199).

156 Londonderry to Graham, 23 February 1844, ibid., 454.

157 Hansard, LXV, c. 113.

158 Ibid., LV, c. 437.

159 Ibid., LXIII, c. 197. 
Parliament was walking when it sought to intervene in the labour market. ${ }^{160}$

One of the early historians of factory legislation - "Alfred" - drew a contrast between those who paid attention to "things", and those who gave priority to human beings. True, he said,

the avowed end of both was the same, namely the improvement of all, but the means leading to the end were opposed: the free school of economists said - "All interference is wrong, get cheapness, and whatever else is needful will follow in its train." The supporters of factory regulation said "Check excessive and unnatural labour, care for health and morals, and whatever else is needful will follow in their train." 161

It is, perhaps, unjust to either Buddle or Londonderry to say they valued "things" before human beings; nevertheless it is clear that, in simplistic terms, it is on this side of "Alfred's" "impassable gulf" that they must be placed. "The national community", wrote Buddle, "is a great machine a great manufactory - and all its departments must be duly balanced and proportioned to enable it to work smoothly". The "cant-cry" of humanitarianism, which Buddle noted had become "the fashion of the day", would, he believed, if carried to its logical extent, "as some would seem to wish, in the end deprive us of pitmen, sailors, soldiers and all." 162 Buddle's fellow agent, James Loch, was equally scathing. "It is a sad, meddling, busybody age", he wrote when Ashley's commission was appointed in 1840, with "everyone taking care of his neighbour's actions". Loch shared with many of the critics of the bill the view that it was "loosening the authority and the duty of the parent towards the child", ${ }^{163}$ but Fox Maule, seconding Ashley's original motion for inquiry, had anticipated such an argument; it was, he asserted, their duty "to protect those children against the tyranny of their parents, and against the temptations to which they were subject". Though the inquiry proposed would interfere between parent and child, Parliament should remember that "from the report of the factory commissioners, that had proved to be necessary". 164

Those who conducted the inquiry themselves reflected the balance of the economic debate. Sub-commissioner Kennedy argued that the same 160 Ibid., LXV, cc. 571-78, 583.

161 "Alfred", The History of the Factory Movement (1857), quoted by W. C. Lubenow, The Politics of Government Growth (Newton Abbot, 1971), p. 137. For a discussion of the debate on the legitimacy of interference, see ibid., pp. 137-79.

162 Buddle, "Comments on Ashley's Speech". Londonderry paraphrased some of these comments in his speech on 24 June, Hansard, LXIV, cc. 543-44.

163 Mather, After the Canal Duke, op. cit., p. 321.

164 Hansard, LV, c. 1276. 
criteria applied to mines as to cotton mills; the intervention of the legislature was therefore "necessary for the protection of the children who were not able to protect themselves; and also for the protection of the state from the growth of an ignorant, depraved, and dangerous population". ${ }^{165}$ For those who were "of an age of discretion, and capable of making their own contracts", however, he found "no case for any interference with the mode of labour", and the "age of discretion" was not, of course, finite. ${ }^{166}$ Subcommissioner Symons went further, and wanted a law to reduce hours of work at the coal-face to nine, ${ }^{167}$ while Kennedy himself wanted compulsory compensation for accidents. ${ }^{168}$ Perhaps the most explicit was Leonard Horner, one of the Commissioners, who wrote in 1840: "It appears to me that the interposition of the legislature on behalf of children is justified by the most cold and severe principles of political economy" - a remark which perhaps justified those who accused the Commission of "making a case". But Horner was less than fair when he claimed that "the alleged interference with parental authority by such legislation is a mere sophism."169 There were others, notably Lord Brougham, who were prepared to argue that the case was by no means so clearly proven as Horner assumed, and their doubts seem to have been shared by the man responsible for implementing the legislation, Sir James Graham.

Speaking on Fielding's motion on the factories bill some years later, Graham said that the true question was not "shall you compel women and children to work for twelve hours a day or not", but rather "shall you by indirect legislation restrain industrious men from working twelve hours a day for the purpose of earning their livelyhood, though they are willing to undergo the fatigue?" This was not, said Graham, mere pedantry, but adherence to the "strict rules of political economy", which he believed to be "a science [.. . ] tending towards the benefit and general happiness of the nation". ${ }^{170}$ In 1842 Ashley disclaimed all intention to infringe the rules of this "science". "I have never attempted to legislate for the adults, or interpose between master and man", ${ }^{171}$ he said, but Graham, though admitting, in the circumstance of the disclosures made by the

165 For this "social control" argument, see A. J. Heesom, "The Coal Mines Act of 1842, Social Reform, and Social Control", in: Historical Journal, forthcoming.

166 CEC, Appendix to First Report, Pt II, p. 192.

167 Ibid., Pt I, p. 176.

168 Ibid., Pt II, p. 195.

169 L. Horner, On the Employment of Children in Factories (1849), p. 15, quoted by B. Martin, "Leonard Horner: A Portrait of an Inspector of Factories", in: International Review of Social History, XIV (1969), p. 439.

170 Hansard, XC, c. 773.

171 Ibid., LXIII, c. 1348. 
Commissioners, that "the sacred principle" of non-interference with parental control must be sacrificed, ${ }^{172}$ nevertheless shared Brougham's doubts as to the extent to which that interference should go. Graham found Ashley's investigations "embarrassing", for they highlighted evils for which no remedy could be provided. ${ }^{173}$

It was because of his doubts - shared by Peel - about how far remedies could be proposed that the Government's support for Ashley's bill was, in the end, half-hearted. Palmerston accused them of giving in to pressure from their supporters, ${ }^{174}$ but though Londonderry, Wharncliffe, Wellington, and perhaps at this time even Brougham, in the Lords, or, for instance, Attwood in the Commons, were supporters of the Government, Ainsworth and Villiers in the Commons, and Hatherton and Fitzwilliam in the Lords were Liberals. Ashley, who proposed the measure, was a somewhat prickly Conservative, ${ }^{175}$ while Lord Campbell, who proposed the crucial amendment that allowed women to continue in pit-work above ground was, as Peel was quick to point out, a member of the opposition. ${ }^{176}$ This bill, like other social legislation, was not a party question, but one on which men in all good faith could take different viewpoints. ${ }^{177}$ When Buddle recorded that Graham "disapproved of Ashley's notions", ${ }^{178}$ or when Graham himself expressed doubts to Lord Jocelyn, ${ }^{179}$ this was the creaking of conscience of a man caught on the horns of the dilemma of "the strict rules of political economy" and the "sacred principle" of non-intervention.

\section{VI}

The Earl of Devon was doubtless correct when he said that if a small increase in the price of coal, or a diminution of the profits of coal-owners,

172 Ibid., c. 1358.

${ }^{173}$ Graham to Peel, 17 September, quoted in C. S. Parker, Sir Robert Peel from his Private Papers (London, 1899), II, p. 548.

174 Hansard, LXV, cc. 1097-98.

175 N. Gash, "Ashley and the Conservative Party in 1842", in: English Historical Review, LIII (1938), pp. 679-81.

176 Hansard, LXV, cc. 1098-1100.

177 W. O. Aydelotte, "The Conservative and Radical Interpretations of Early Victorian Social Legislation", in: Victorian Studies, XI (1967-68), pp. 225-36. A. J. Taylor, "The Third Marquess of Londonderry", p. 23, note 19, suggests that the Government might have feared alienating the coal interest because of its simultaneous taxation proposals, but though Bell, Ashley's ally, was active against the tax (Hansard, LXIII, c. 1548), Londonderry urged Peel: "Do not be apprehensive as to the coal tax", Londonderry to Peel, 27 March, Peel Papers, loc. cit., 40505, ff. 168-69.

178 Buddle's place-book, 21 June.

179 Ashley's diary, 2 July, loc. cit., p. 429. 
resulted from Ashley's bill, "it would be a cheap price to pay for getting rid of so much misery". ${ }^{180}$ The coal-owners, many of whom believed themselves to be good employers, did not share this point of view. Subcommissioner Symons, when urging his nine-hour day, had prophesied that, while it would be popular with the pit-men, three quarters of the owners would oppose it; but the owners, he said, should appreciate that the consequent reduction in supply would tend to increase profits, a fact which "every practical man of business knows to be true". ${ }^{181}$ The coal-owners (who already regulated supply) felt that any interference with their industry would further damage what was already precarious enough, for, as Buddle wrote in June 1842, "prices are now lower than they have been ever since the disastrous years of 1832 and 1833."182 As the "practical men of business" which they undoubtedly were, it was only natural for the coalowners to disregard the advice of the Poor Law Commissioners, that every man ought to "distrust his own judgement and his own actions in the affairs of others in proportion as his interests and affections are concerned" ${ }^{183}$ No one can take seriously the statement by Lord Londonderry that "he repudiated in the most emphatic manner any pecuniary considerations in his opposition" to Ashley's bill. ${ }^{184}$ But the opposition of other coal-owners - perhaps even of Londonderry himself - was not exclusively based on pecuniary concern and naked self-interest.

The coal-owners objected to the exclusion of women not because, on the whole, they employed women, but because they said excluding women would cause hardship. They were proved to be right. As Tremenheere discovered, when he reported on the coal mines of Scotland, the provisions of Ashley's act had fallen with "great severity" on the women who had been excluded. Mature able-bodied women were not entitled to poor relief - pace Lord Campbell - because it was assumed they could get other work, but, as Ashley's opponents had warned, and Tremenheere confirmed, this was "a presumption which is far from being sustained by the fact". Their case, wrote Tremenheere, "merits particular sympathy, inasmuch as they have been deprived of their former means of livelyhood on moral grounds, and with a view to moral results, which concern the rising and future generations, far more than they can be supposed to influence

180 Hansard, LXV, cc. 583-84.

181 CEC, Appendix to First Report, Pt I, p. 177.

182 Buddle to Londonderry, 6 June.

${ }_{183}$ Report on the Administration and Practical Operation of the Poor Laws [PP, 1834, XXVII], p. 116.

184 Morning Post, 26 July; this speech does not appear in Hansard. 
themselves." ${ }^{185}$ Londonderry may have been wrong to discount "praiseworthy humanity"186 in excluding women, but Joseph Hume was right when he condemned Ashley for not taking sufficient care to see what the effect of his bill would be. ${ }^{187}$

Hume was right, too, when he said that Ashley "seemed to speak as if no other man than himself had a desire to see the sufferings of these unfortunate creatures relieved". ${ }^{188}$ Ashley said his observations of the "enormous toil" of part of the labouring population, and the "total disemployment" of others, had convinced him that he "had a right to interpose on behalf of the children and young persons, to redress the balance, and to avert the mischief, by shortening the hours of labour, and by that means to call into action those who were unemployed." 189 Again, Ashley was over-optimistic. For instance, in the Bridgewater collieries, acknowledged to be well run by the humanitarian Francis Egerton, the trustees sought to improve on Ashley's Act, which had forbidden children under ten, by extending its provisions to those under twelve, but at Dixon Green colliery the plan had to be abandoned under pressure from the pitmen, who resented having to do boys' work. ${ }^{190}$ Ainsworth's strictures on the impracticability of the relay system were, perhaps, vindicated. Robert Fergusson was doubtless right when he said that the arguments of Ainsworth and others in favour of the employment of young children - the displacement of capital, the displacement and consequent sufferings of labour, the shutting of thin-seam collieries with consequent loss to the national "machine" - afforded "a fine scope for the ingenuity of the expediency-monger and the casuist". ${ }^{191}$ But historians should perhaps be rather more careful in dismissing them as nothing more.

It was after all no coal-owner, but Lord Radnor, a radical landowner, who was the most fundamentalist opponent of the bill. He was "from the first disposed to consider this bill to be unnecessary", and "still less necessary" after Devon accepted the amendments. Radnor admitted all the facts to be as the bill's protagonists stated, but that, he claimed,

185 First Report from the Commissioner Appointed under the Provisions of the Act 5 \& 6 Vict., c. 99 [PP, 1844, XVI], p. 4.

186 Hansard, LXV, c. 582.

187 Ibid., LXIX, c. 476. See also A. V. John, "Colliery Legislation and its Consequences: 1842 and the Women Miners of Lancashire", in: Bulletin on the John Rylands Library, LXI (1978), pp. 78-114.

188 Hansard, LXV, c. 582.

189 Ibid., LXIII, c. 1348.

190 Mather, After the Canal Duke, p. 323

191 [Robert Ferguson,] "Colliers and Collieries", in: Quarterly Review, LXX (1842), p. 181 . 
was no argument in favour of the passing of the bill. Women and children might be employed in collieries, and might be improperly or indecorously employed, but the condemnation of the system, or even the desire to put an end to it, was not a sufficient ground for passing an Act of Parliament to carry out such a desire. ${ }^{192}$

And if Radnor's ideas represented one side of the argument, Ashley was by no means totally committed to the other. In his article in the Quarterly Review he had admitted that children may "with perfect propriety, with advantage to their parents and themselves, be employed to a certain extent in the labour of looms and shops". Ashley did not deny the propriety, but queried the necessity, and sought to replace child labour with a system of moral education. ${ }^{193}$ The coal-owners were more ready to accept the necessity, and doubted the practicality of the alternative.

Radnor noted in one of his speeches that "a great feeling" had been raised against the way mines were conducted, though "nobody very well knew why". The basic reason for the feeling was the publicity (and consequent outcry) which Ashley had deliberately fostered, and which the Commission's report, with its wood-cuts, had done much to stimulate, which carried the measure forward. But as Radnor pointed out, "the bill was founded on that feeling, but feeling was at all times a bad ground of action". ${ }^{194}$ One small example of the fault of rushing the bill onward was shown in the poor draftsmanship of the clause on inspectors.

But more lay behind the feeling than concern for women and children in the pits. Edward Baines believed that there existed a general prejudice against the manufacturing districts, which he said had been "growing up ever since the first Committee on Factory Labour" and certainly was "of much older date than [...] the Report of the Children's Employment Commissioners". This prejudice, he said, had convinced people that such was the "worthlessness of the whole manufacturing population" that the Standard newspaper had felt justified in declaring that "England would be as great and powerful, and all useful Englishmen would be as rich as they are, though one ruin should engulph all the manufacturing towns and

192 Hansard, LXV, cc. 113-15, 584-85. Radnor was the only one who promised to support Londonderry if he divided on the second reading, but Londonderry thought "it was not prudent to show up weakness in pressing a division", Londonderry to Buddle, 15 July, National Coal Board Manuscripts 1/JB/1808. Radnor was presumably one of the three who voted for Londonderry's motion against the recommittal of the bill, Morning Post, 26 July. The numbers are not recorded in Hansard, and no list of names has apparently survived. For Radnor, see R. K. Huch, The Radical Lord Radnor: The Public Life of Viscount Folkestone, Third Earl of Radnor (Minneapolis, 1977).

193 [Lord Ashley,] “Infant Labour”, in: Quarterly Review, LXVII, (1840), p. 175.

194 Hansard, LXV, c. 114. 
districts of Great Britain!" 195 The Morning Post did not go as far as the Standard, but it did assert that the way to avoid the evils of society was to afford the labouring population "an opportunity to earn subsistence by their labour in some other way than the drilled and drudging attendance upon the mighty steam engine". ${ }^{196}$ Echoes of this anti-industrial attitude can be found in the speech of the Bishop of London on the bill, when he claimed that whatever evils were to be found in the rural population were "fearfully exaggerated" in the manufacturing districts, ${ }^{197}$ or perhaps in sub-commissioner Thomas Tancred's reaction to Coatbridge: "Everything that meets the eye or ear here tells of slavish labour united to brutish intemperance." 198 Even Lord Ashley has been accused of taking up the factory question more from dislike of the mill-owners than from sympathy for the mill workers. ${ }^{199}$ Such attitudes were hardly likely to exist side by side with sympathy for even reasoned pleas based on the risks inherent from a business point of view in Government inspection.

The Times struck a more rational note when it wrote of the coal-owners, that "such persons should be taught that money-making is not the whole duty of man", and that the coal-owners were under an obligation to see not only that profits were made, "but how these profits are made, whether out of free and well-regulated employment of labour, or out of a barbarous and indecent system - which disclaims any other law than that of productiveness." 200 The Northern coal-owners would not have recognised this, as it was meant to be, as an accusation. When the Northern Coal Trade drafted their first observations against the bill, in what Ashley described as "a feeble paper, quite in the style of the old apologies of the Factory masters", he claimed their object was to throw "the mantle of their comparative merit over the enormities of the general practice". ${ }^{201}$ In introducing his bill Ashley conceded "in justice to the great coal owners of the North", that "if they had been the only parties with whom we had to deal, the necessity for this bill would perhaps not have existed", ${ }^{202}$ a sentiment borne out by sub-commissioner Leifchild, who told Buddle that the "painful instances" so common elsewhere were happily not apparent in Northumberland and Durham. ${ }^{203}$ The Morning Chronicle, Ashley's great ally among the

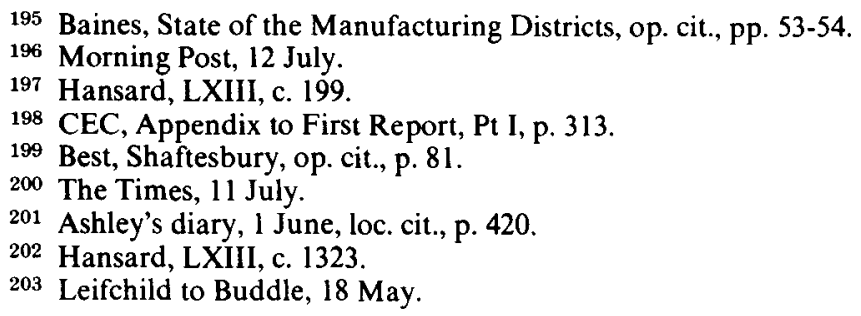


national press, exonerated Lords Londonderry and Fitzwilliam, and was sure that "other noble proprietors stand equally clear". "Their own characters are safe; that should content them", the Chronicle concluded.204 They and their fellow owners did not rest content; but their opposition to Ashley's bill was not a defence of their own characters - nor yet exclusively of their own self-interest.

204 Morning Chronicle, 10 May. 